\title{
Gasification of biomass for production of syngas for biofuel
}

\author{
Umesh Adhikari $^{1}$ Marianne S. Eikeland ${ }^{1}$ Britt M. Halvorsen ${ }^{1}$ \\ ${ }^{1}$ Department of Process Energy and Environmental Technology, Telemark University College, N-3901 Porsgrunn, \\ Norway
}

\begin{abstract}
Steam gasification is used to produce a high-quality synthesis gas. In this work, the emphasis is on the composition of syngas production which can be further processed for the conversion of biomass to transport biofuels. Biomasses such as wood chips are heated in a gasification reactor to produce a mixture of gases, mainly $\mathrm{CO}, \mathrm{CO}_{2}, \mathrm{H}_{2}$, and $\mathrm{CH}_{4}$.

Flow sheets for steam gasification of woody biomass have been developed and the process have been simulated using Aspen Plus. The Peng-Robinson equation of state with Boston-Mathias is selected for the model. The model describes the hydrodynamic parameter and reaction kinetics modeling.

Gasification temperature, steam to biomass ratio (STBR), and steam temperature are the most important operating parameters that are considered and studied to examine the gasifier performance. The impact of these process parameters on gasification is determined by sensitivity analysis. The simulation results show that a synthesis gas with a high content of $\mathrm{H}_{2}$ and $\mathrm{CO}$ is obtained for the optimized gasification process.
\end{abstract}

Keywords: Steam gasification, Aspen Plus, Product gas

\section{Introduction}

Energy demand is increasing day by day in today's world and energy crisis may come in near future. Together with this, emissions of different gases such as carbon dioxide cause global warming and climate change. Traditional fuels such as petroleum, coal and natural gas are the principal sources of world's energy demand in the current situation ( $\mathrm{Hu}, \mathrm{Yu}, \& \mathrm{Lu}, 2012)$. There is a need for alternative sources of energy in near future, and one of the alternative fuels can be biomass. Biomass gasification is one of the appropriate solutions. As an alternative energy source, biomass can be used in power plants for combined heat and power production.

A Lot of progress has been made on biomass gasification during the past few decades. Among the different gasifier types such as fixed bed, fluidized bed and dual fluidized bed gasifiers, development of dual fluidized bed gasifier not only increased the efficiency but also made it possible to gasify various types of biomass such as wood, agricultural residues, and municipal solid wastes.
In Dual Fluidized Beds (DFB) heat is provided to the gasification reactor by circulating hot bed materials (Pröll, Rauch, Aichernig, \& Hofbauer, 2007).The main idea of this gasification system is to produce the nitrogen free of syngas for biofuel production.

\subsection{Biomass to biofuel}

Biochemical and Thermochemical conversion are two different ways of converting biomass into biofuel. Conversion of biomass into liquid or gaseous fuels by anaerobic digestion or fermentation is a biochemical conversion process. In the thermochemical process, biomass solid raw material is converted to fuel gas or syngas $\left(\mathrm{CO}, \mathrm{H}_{2}\right.$, and $\left.\mathrm{CO}_{2}\right)$. The syngas that is produced can be converted to fuels like synthetic gasoline and diesels (Kumar, Jones, \& Hanna, 2009). For this application, Fischer-Tropic (FT) is one of the most popular processes.

Synthesis gas mainly produced from biomass gasification, coal gasification and natural gas reforming is further used for the production of hydrocarbons. Researchers have shown their interest in (FT) technology due to fast depletion of fossil fuels, increasing the price of crude oil and global warming problem in today's world(Choudhury \& Moholkar, 2013).

\subsection{Principle of Steam gasification of Biomass}

The general process description of the steam gasification is shown in Figure 1-1. The principle is the same as for a dual fluidized bed gasifier having a combustion and a gasification reactor. Here, biomass is devolatized in RYield (Reactor) where conversion of non-conventional stream biomass into conventional components $\left(\mathrm{C}, \mathrm{H}_{2}, \mathrm{O}_{2}, \mathrm{~N}_{2}, \mathrm{~S}\right)$ takes place. The gasification process is simulated using a Gibbs reactor in which steam is supplied to the reactor and char combustion takes place in reactor RStoic with the supply of air. The heat that is produced during the combustion is used in the gasifier for the gasification reaction. Finally, flue gas $\left(\mathrm{N}_{2}, \mathrm{CO}_{2}\right.$, and excess $\left.\mathrm{O}_{2}\right)$ and solid (bed materials) is separated by using cyclone separator. 


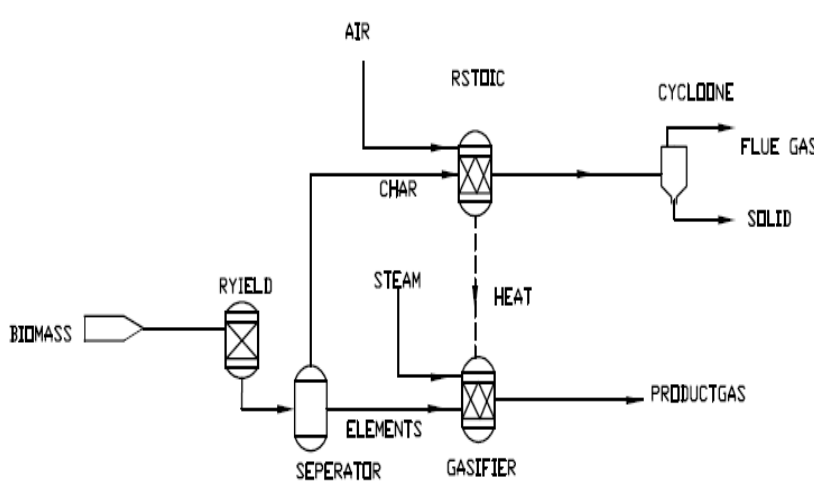

Figure 1-1: Steam gasification of biomass

\subsection{Reaction chemistry}

Steam is used for the gasification process. The equilibrium reaction takes place in the Gibbs reactor. A detailed description of the reactions in the gasification process is given by the reaction (R1), (R2), (R3), (R4) and (R5). The chemical reaction for endothermic and exothermic reactions are given in Table 1-1(Zanzi, Sjöström, \& Björnbom, 2002). In the steam gasification, reaction $(\mathrm{R} 1)$ is dominant and if the gasification medium is air or oxygen then (R2) is the dominant reaction. Reaction (R3) occurs with freshly devolatilized char. For the generation of more $\mathrm{H}_{2}$, the reaction (R4) plays a major role. Reactions (R1),( R2) and (R5) are highly endothermic whereas (R3) and (R4) are mild exothermic(Basu, 2010).

The general reaction in biomass gasification is shown as in Equation 1 (Authier \& Lédé, 2013).

$$
\text { wood } \rightarrow \mathrm{H}_{2}, \mathrm{CO}, \mathrm{CO}_{2}, \mathrm{CH}_{4}, \text { tars, char }
$$

Table 1-1. Chemical Reaction

\begin{tabular}{|c|c|}
\hline Chemical reactions & Symbol \\
\hline $\begin{array}{l}\text { Steam gasification } \\
\qquad(s)+H_{2} \mathrm{O} \Leftrightarrow \mathrm{CO}+\mathrm{H}_{2}\end{array}$ & (R1) \\
\hline $\begin{array}{l}\mathrm{CO}_{2} \text { gasification } \\
\mathrm{C}(\mathrm{s})+\mathrm{CO}_{2} \Leftrightarrow 2 \mathrm{CO}\end{array}$ & (R2) \\
\hline $\begin{array}{l}\text { Methanation } \\
0.5 C(s)+H_{2} \Leftrightarrow 0.5 \mathrm{CH}_{4}\end{array}$ & (R3) \\
\hline $\begin{array}{l}\text { Water gas shift } \\
\mathrm{CO}+\mathrm{H}_{2} \mathrm{O} \Leftrightarrow \mathrm{CO}_{2}+\mathrm{H}_{2}\end{array}$ & (R4) \\
\hline $\begin{array}{l}\text { Methane -reforming } \\
\mathrm{CH}_{4}+\mathrm{H}_{2} \mathrm{O} \Leftrightarrow \mathrm{CO}+3 \mathrm{H}_{2}\end{array}$ & (R5) \\
\hline
\end{tabular}

\section{Aspen Plus Simulation}

Aspen Plus simulation software is selected for modeling the gasifier in this research. In many research projects, this software is being used for modeling coal and biomass gasification. It is a sequential modular simulator that has links to a variety of specialized software like heat exchanger design, dynamic simulation and batch process modeling. (Schefflan). In this process simulation is carried out first by specifying material and energy streams on the simulator blocks. Peng-Robinson equation of state with Boston-Mathias (PR-BM) has been selected as the property package to calculate properties of different components during the gasification process. The simulated process diagram is shown in Figure 2-1.

The following assumptions have been considered for the process simulated in Aspen Plus.

- Isothermal and Steady state process.

- Pressure drop are neglected.

- Instantaneous devolatilization of biomass. The main volatile products are $\mathrm{H}_{2}, \mathrm{CO}, \mathrm{CO}_{2}, \mathrm{CH}_{4}$.

- Heat loss from the reactors is neglected.

- Char contains only carbon and ash.

- Tars and other heavy products are assumed as nonequilibrium.

HCOALGEN and DCOALIGT property models have been chosen for both biomass and ash that are nonconventional to estimate the biomass enthalpy of formation, specific heat capacity and density.

Calculators and design specification blocks are used in the model simulation. Calculators have been used to calculate the product composition after the breakdown of elements and to determine the air mass flow rate. FORTRAN statements are entered to operate the calculator for breakdown of elements. Design specification block have been used for executing the steam flow rate. Details can be found in the Master Thesis(Adhikari, 2015). 


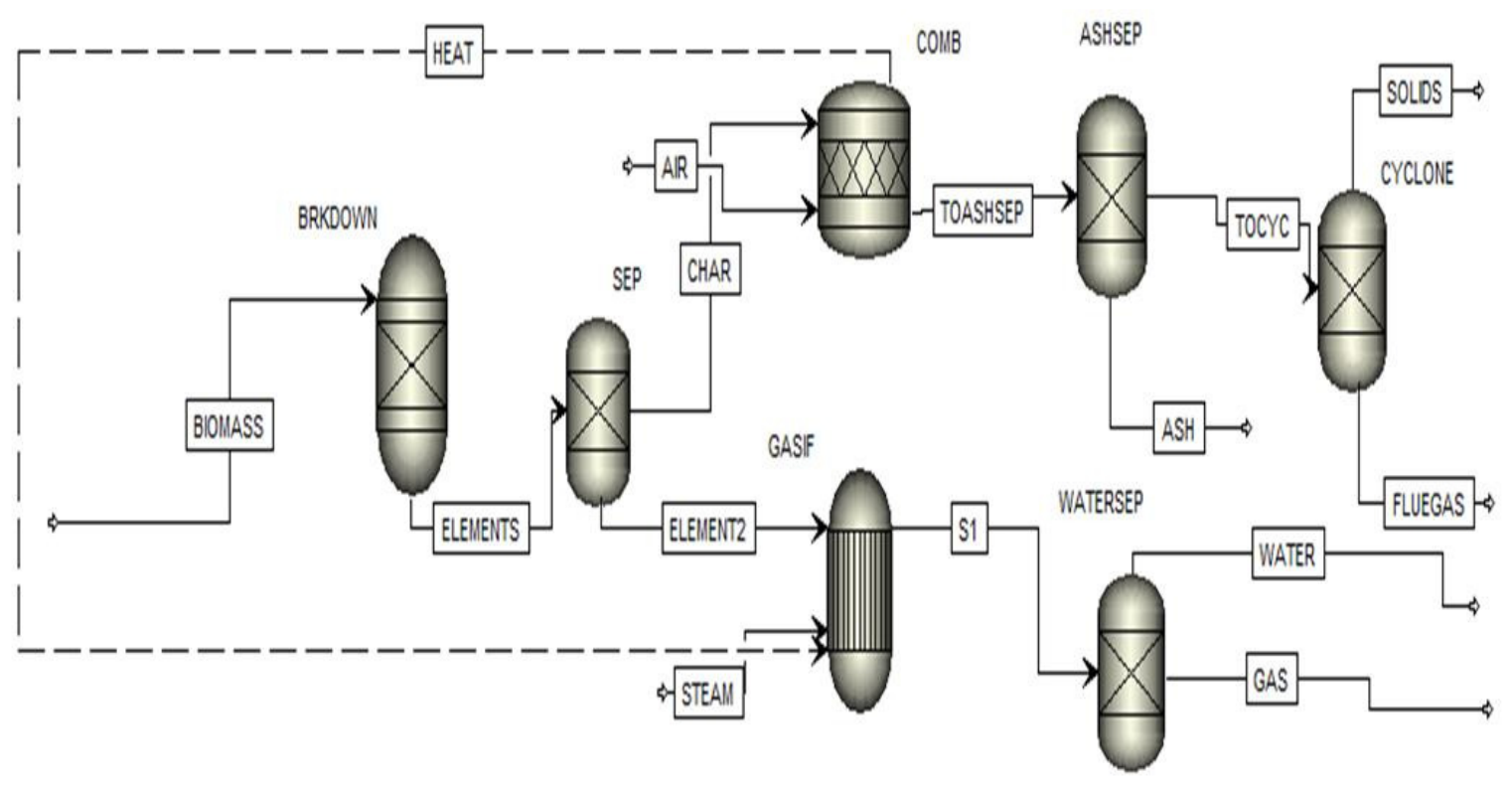

Figure 2-1: Simulated Process Diagram

Table 2-1 gives an overview of the reactor blocks used in the simulations.

Table 2-1. Aspen Plus Reactor Block

\begin{tabular}{|c|c|}
\hline Description & $\begin{array}{l}\text { Reactor } \\
\text { Block ID }\end{array}$ \\
\hline $\begin{array}{l}\text { This reactor model is useful when } \\
\text { reaction stoichiometry and } \\
\text { kinetics are unknown and yield } \\
\text { distributions elements or data are } \\
\text { known. }\end{array}$ & RYIELD \\
\hline $\begin{array}{l}\text { The model is mainly useful when } \\
\text { reaction stoichiometry is } \\
\text { unknown, but pressure and } \\
\text { temperature are known. It models } \\
\text { single phase chemical equilibrium } \\
\text { by minimizing Gibbs free energy. }\end{array}$ & RGIBBS \\
\hline $\begin{array}{l}\text { SEP have been used in the } \\
\text { simulation to split a portion of } \\
\text { char into the gasifier and } \\
\text { combustor. ASHSEP have been } \\
\text { used to separate the ash, } \\
\text { WATERSEP is used to separate } \\
\text { water from gas and } \\
\text { CYCLONESEP to separate the } \\
\text { product mixture. }\end{array}$ & SEPARATOR \\
\hline $\begin{array}{l}\text { This reactor model is mainly used } \\
\text { for modeling the char combustion. }\end{array}$ & RSTOIC \\
\hline
\end{tabular}

defined as biomass in the simulation model. The information about this analysis is given in Table 2-2 and Table 2-3(Doherty, Reynolds, \& Kennedy, 2013).

Table 2-2. Biomass composition (Ultimate Analysis) defined in Aspen Plus

\begin{tabular}{|l|l|l|}
\hline $\begin{array}{l}\text { Ultimate Analysis (Dry } \\
\text { basis) }\end{array}$ & $\begin{array}{c}\text { Biomass } \\
(w t \%)\end{array}$ & $\begin{array}{l}\text { Ash } \\
(w t \%)\end{array}$ \\
\hline Carbon & 51.19 & 0 \\
\hline Hydrogen & 6.08 & 0 \\
\hline Oxygen & 41.3 & 0 \\
\hline Nitrogen & 0.2 & 0 \\
\hline Sulphur & 0.02 & 0 \\
\hline Chlorine & 0.05 & 0 \\
\hline Ash & 1.16 & 100 \\
\hline
\end{tabular}

Table 2-3. Biomass composition (Proximate Analysis) defined in Aspen Plus

\begin{tabular}{|l|l|l|}
\hline $\begin{array}{l}\text { Proximate Analysis (Dry } \\
\text { basis) }\end{array}$ & $\begin{array}{c}\text { Biomass } \\
(w t \%)\end{array}$ & $\begin{array}{l}\text { Ash } \\
(w t \%)\end{array}$ \\
\hline Volatile matter & 80 & 0 \\
\hline Fixed carbon & 18.84 & 0 \\
\hline Ash & 1.16 & 100 \\
\hline Moisture & 20 & 0 \\
\hline
\end{tabular}

Biomass is specified as non-conventional components in ASPEN Plus. Ultimate and Proximate analysis is 


\subsection{Feed Specification}

Biomass feed before starting of the simulation have been specified. Biomass with a flow rate of $1500 \mathrm{~kg} / \mathrm{hr}$. temperature $25^{\circ} \mathrm{C}$ and pressure $1 \mathrm{~atm}$ is specified.

\subsection{Break down of Elements}

The 'RYield' reactor is used to model the breakdown of the elements. It converts the non-conventional biomass into conventional components that are determined and set using a calculator block.

\subsection{Gasification}

For gasification, RGibbs model is used as the main reactor that handles three phase chemical equilibrium. This reactor calculates the syngas composition by minimizing the Gibbs free energy and assumes complete chemical equilibrium. Gasification Reactions (R1), (R2), (R3), (R4), (R5) have been taken with zero temperature approach for all the reactions. The principal product of the char gasification is the syngas $\left(\mathrm{H}_{2}\right.$ and $\left.\mathrm{CO}\right)$ which also contains other elements like $\mathrm{H}_{2} \mathrm{O}, \mathrm{N}_{2}, \mathrm{~S}, \mathrm{Cl}_{2}, \mathrm{CO}_{2}, \mathrm{CH}_{4}$, and ash. The mass fractions of all these elements are given in Table 2-4.

Table 2-4. Mass fraction of the elements resulted from simulation

\begin{tabular}{|l|l|}
\hline Elements & $\begin{array}{c}\text { Mass } \\
\text { fraction }\end{array}$ \\
\hline $\mathrm{H}_{2}$ & 0.04 \\
\hline $\mathrm{CO}$ & 0.32 \\
\hline $\mathrm{H}_{2} \mathrm{O}$ & 0.45 \\
\hline $\mathrm{N}_{2}$ & 0.0013 \\
\hline $\mathrm{S}$ & 0.08 \\
\hline $\mathrm{CO}_{2}$ & 0.11 \\
\hline $\mathrm{CH}_{4}$ & 0.00 \\
\hline
\end{tabular}

\subsection{Combustion}

The RStoic model has been used for the combustion process. The model involves that 'no chemical reactions' are specified and the option of a generation of combustion reactions is selected. The air stream 'AIR' is fed to this block reactor with the composition of $0.79 \mathrm{~N}_{2}$ and $0.21 \mathrm{O}_{2}$ and temperature of $450^{\circ} \mathrm{C}$ is specified (Pröll \& Hofbauer, 2008).

\section{Simulation Analysis}

The model have been used to perform a sensitivity analysis. To study the gas production, four main gases $\left(\mathrm{H}_{2}, \mathrm{CO}, \mathrm{CO}_{2}, \mathrm{CH}_{4}\right)$ as stated by (Lv et al., 2004) are considered. Mainly the influence of reactor temperature, steam temperature and steam to biomass ratio (STBR) on the product gas composition is studied.

\subsection{Gasification Temperature}

The gasification temperature highly influences on the syngas composition. To determine the effect on the composition, the temperature is varied from 600 to $1100^{\circ} \mathrm{C}$. The results are presented in Figure 3-1.

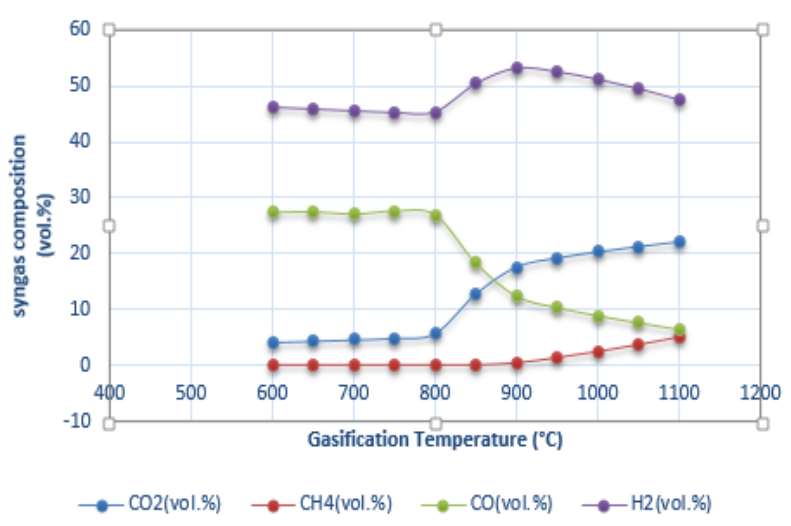

Figure 3-1. Effect of gasification temperature on syngas composition

Over this range, the minimum composition of $\mathrm{H}_{2}$ is (45.81vol. \%), and the maximum is (53.27 vol. \%). The minimum and maximum compositions for $\mathrm{CO}, \mathrm{CO}_{2}$, and $\mathrm{CH}_{4}$ are $6.44 \%-27.64 \%, 4.16 \%-22.11 \%$ and 0 $5.08 \%$ respectively. From the results, it is clear that the temperature of the gasifier should be maintained at 800 $-850^{\circ} \mathrm{C}$ to produce a higher amount of product gas. The Lower temperature cannot provide the required heat energy for the gasification reaction and therefore, produces less amount of product gas (mainly $\mathrm{CO}$ and $\mathrm{H}_{2}$ ).

\subsection{Steam Temperature}

The influence on the syngas composition with variation in steam temperature is shown in the Figure 3-2. The steam temperature was varied from 450 to $1000^{\circ} \mathrm{C}$ to check the volume percent of syngas composition.

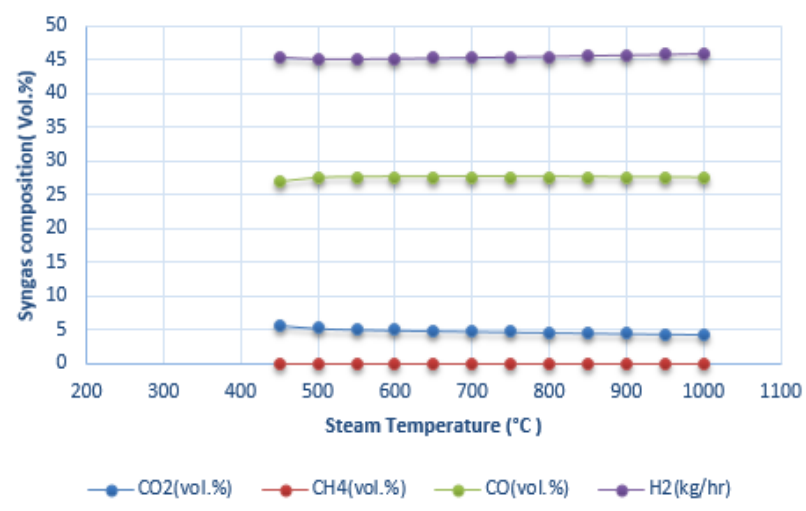

Figure 3-2. Plot of product gas composition versus steam temperature 
As can be seen from the figure, the steam temperature does not have any significant influence on the syngas composition. It is therefore not of big importance to preheat the steam to a high temperature before feeding it to the reactor.

\subsection{Steam to Biomass Ratio (STBR)}

STBR has a significant impact on the syngas composition. Over the STBR range, $\mathrm{H}_{2}$ increases from 45.39 to 48.64 vol. \%. There is no influence of STBR on the composition of $\mathrm{CH}_{4}$. However, there is a gradual increase in the $\mathrm{CO}_{2}$ content. From the STBR value of about 0.7 there is a sharp decrease in the $\mathrm{CO}$ composition as is shown Figure 3-3.

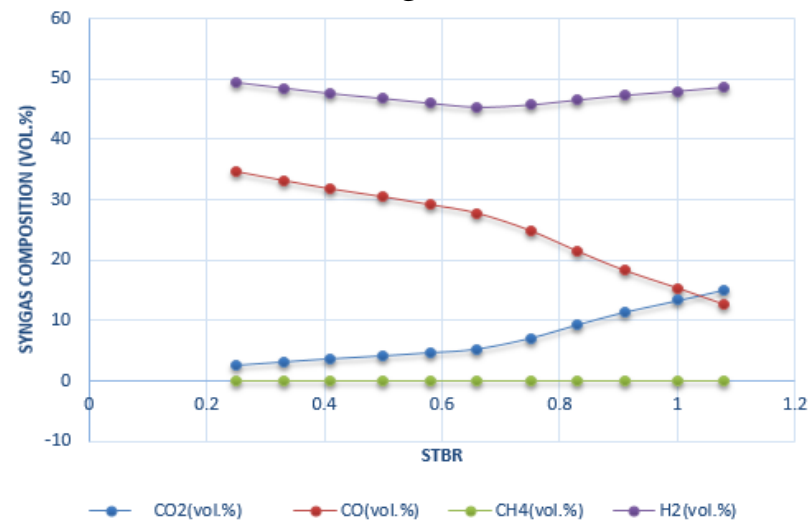

Figure 3-3. Effect of STBR on syngas composition

The amount of hydrogen increases with increased steam injection and the amount of carbon monoxide decreases which can be explained by the water- gas shift reaction (R4). According to reaction (R3) increasing amount of steam increases the fraction of hydrogen in the syngas.

\section{Comparison of the result}

Steam gasification is used to produce a high-quality product gas $\left(\mathrm{CO}, \mathrm{H}_{2}, \mathrm{CO}_{2}\right.$, and $\left.\mathrm{CH}_{4}\right)$ and these gas are further processed for production of synthesis fuel. For this gas quality, gas composition and purity are the main important parameter. The main objective is to look at the generated product gas composition. The product gas composition that is obtained from the simulation is compared with the experimental result in the Table 4-1.
Table 4-1. Experimental and model value of producer gas composition

\begin{tabular}{|l|l|l|}
\hline Components & $\begin{array}{l}\text { Experimental } \\
\text { value(vol\% dry } \\
\text { basis)(Schuster, } \\
\text { Löffler, Weigl, \& } \\
\text { Hofbauer, 2001) }\end{array}$ & $\begin{array}{l}\text { Model } \\
\text { results(vol\% } \\
\text { dry basis) }\end{array}$ \\
\hline Hydrogen $\left(\mathrm{H}_{2}\right)$ & 56.18 & 58.37 \\
\hline $\begin{array}{l}\text { Carbon } \\
\text { monoxide(CO) }\end{array}$ & 31.17 & 34.11 \\
\hline $\begin{array}{l}\text { Carbon dioxide } \\
\left(\mathrm{CO}_{2}\right)\end{array}$ & 12.42 & 7.24 \\
\hline Methane $\left(\mathrm{CH}_{4}\right)$ & 0.11 & Negligible \\
\hline Others & 0.11 & 0.28 \\
\hline
\end{tabular}

There are still more challenges and questions regarding the improvement of simulation. The result that is obtained from the simulation can be modified to improve the simulations results. For this verification of the result is necessary which may be possible in the real plant experiment.Simulation based on the kinetic model can be studied. Also, simulation of gasification process can be done with $\mathrm{CO}_{2}$ capture process to study the behavior of syngas production.

\section{Conclusions}

A simulation study considering biomass (wood) as the raw material to a Dual fluidized -bed gasifier was carried out using the proximate and ultimate analysis in the model. The process simulation tool Aspen Plus was used in this study. Different unit operation blocks were combined and the required kinetic expressions and hydrodynamic models were developed to carry out the simulations. The simulation results show that a synthesis gas with a high content of $\mathrm{H}_{2}$ and $\mathrm{CO}$ on a dry basis.

The mixture of gas can be further processed for conversion of biomass to transport biofuel such as gasoline, diesel and jet fuels and the process FT (Fischer-Tropsch Synthesis) is getting more popular during recent years for production of renewable fuels.

The impact of gasification temperature, steam temperature, steam to biomass ratio (STBR) on the gasification process are determined by sensitivity analysis. The optimum gasification temperature is found to be about $800^{\circ} \mathrm{C}$ and the optimum STBR about 0.65 . 


\section{References}

Adhikari, U. (2015). Gasification of biomass for production of syngas for biofuel Master Thesis (pp. 27-50): Telemark University

College, Faculty of Technology, Porsgrunn, Norway, 2014.

Authier, O., \& Lédé, J. (2013). The image furnace for studying thermal reactions involving solids. Application to wood pyrolysis and gasification, and vapours catalytic cracking. Fuel, 107, 555-569.

Basu, P. (2010). Biomass gasification and pyrolysis: practical design and theory: Academic press.

Choudhury, H. A., \& Moholkar, V. S. (2013). An Optimization Study of Fischer-Tropsch Synthesis Using Commercial Cobalt Catalyst. 2(1), 31-39.

Doherty, W., Reynolds, A., \& Kennedy, D. (2013). Aspen plus simulation of biomass gasification in a steam blown dual fluidised bed. 212-220.

Hu, J., Yu, F., \& Lu, Y. (2012). Application of Fischer-Tropsch synthesis in biomass to liquid conversion. Catalysts, 2(2), 303-326.

Kumar, A., Jones, D. D., \& Hanna, M. A. (2009). Thermochemical biomass gasification: a review of the current status of the technology. Energies, 2(3), 556581.

Lv, P., Xiong, Z., Chang, J., Wu, C., Chen, Y., \& Zhu, J. (2004). An experimental study on biomass air-steam gasification in a fluidized bed. Bioresource technology, 95(1), 95-101.

Pröll, T., \& Hofbauer, H. (2008). H 2 rich syngas by selective CO 2 removal from biomass gasification in a dual fluidized bed system-process modelling approach Fuel Processing Technology, 89(11), 1207-1217.

Pröll, T., Rauch, R., Aichernig, C., \& Hofbauer, H. (2007). Performance characteristics of an 8 MW (th) combined heat and power plant based on dual fluidized bed steam gasification of solid biomass. 937944.

Schefflan, R. Introduction to Aspen Plus. Teach Yourself the Basics of Aspen Plus ${ }^{\mathrm{TM}}, 1-19$.

Schuster, G., Löffler, G., Weigl, K., \& Hofbauer, H. (2001). Biomass steam gasification - an extensive parametric modeling study. Bioresource technology, 77(1), 71-79. doi: http://dx.doi.org/10.1016/S0960-8524(00)001152

Zanzi, R., Sjöström, K., \& Björnbom, E. (2002). Rapid pyrolysis of agricultural residues at high temperature. Biomass and Bioenergy, 23(5), 357-366. 